cứu cho thấy sự giảm nồng độ serotonin trong dịch não tủy là không có tương quan với trâm cảm trên bệnh nhân Parkinson [6]. Vì vậy, cần có những nghiên cứu với cõ̃ mẫu lớn hơn để xác định vấn đề này.

Hoạt động của hệ thống serotonin có liên quan chặt chẽ đến chức năng nhận thức và trí nhớ. Vì vậy, sự suy giảm các chức năng này có thể tương quan với sư giảm hoat động của hê thống serotonin trên bệnh nhân Parkinson, mà biểu hiện bằng sự giảm nồng độ của serotonin trong dich não tủy. Kết quả nghiên cứu của chúng tôi cho thấy nồng độ serotonin trong dịch não tủy ở nhóm bệnh nhân có suy giảm suy giảm nhận thức là thấp hơn có ý nghĩa thống kê so với ở nhóm bệnh nhân Parkinson không có suy giảm nhận thức. Kết quả này cùng với các kết quả trên đây đã cho thấy sự mối liên quan rõ rệt giữa sự thay đổi nồng độ serotonin trong dịch não tủy với các triệu chứng vận động cũng như các triệu chứng ngoài vận động trên bệnh nhân Parkinson.

\section{KẾT LUẬN}

Tuổi trung bình nhóm bệnh nhân Parkinson là 63,18 \pm 9,46 tuổi , 90,2\% bệnh nhân Parkinson từ 50 tuối trở lên, trong đó BN từ 60-69 tuổi chiếm 39,3\%. Nồng độ trung bình serotonin dịch não tủy ở nhóm bệnh giảm có ý nghĩa so với nồng độ serotonin dịch não tủy nhóm chứng. Giữa nồng độ serotonin dịch não tủy với thời gian mắc bệnh có mối tương quan nghịch với $r=-$ $0,649, p<0,001$. Nồng độ serotonin dịch não tủy trung bình nhóm bệnh giảm dần theo mức độ nặng của bệnh và giai đoạn bệnh, trầm cảm. Nồng độ serotonin dịch não tủy trung bình bệnh nhân Parkinson có suy giảm nhận thức giảm có ý nghĩa so với bệnh nhân Parkinson không có suy giảm nhận thức.

\section{TÀI LIỆ THAM KHẢO}

1. Chuquilin-Arista, F., T. Alvarez-Avellon, and M. Menendez-Gonzalez (2019), Prevalence of Depression and Anxiety in Parkinson Disease and Impact on Quality of Life: A Community-Based Study in Spain. J Geriatr Psychiatry Neurol, p. 891988719874130.

2. Politis, M. and C. Loane (2011), Serotonergic dysfunction in Parkinson's disease and its relevance to disability. ScientificWorldJournal, 11: p. 1726-34.

3. Pagano, G., et al. (2016), Age at onset and Parkinson disease phenotype. Neurology, 86(15): p. $1400-1407$.

4. Nguyễn Bá Nam (2016), Nghiên cứu đặc điểm lâm sàng và nồng độ homocysteine huyết tương ở bệnh nhân mắc bệnh Parkinson, Học viện Quân y.

5. Johansson, B. and B.E. Roos (1971), 5Hydroxyindoleacetic acid in cerebrospinal fluid of patients with Parkinson's syndrome treated with LDOPA. European Journal of Clinical Pharmacology, 3(4): p. 232-235.

6. Olivola, E., et al.(2014), Serotonin impairment in CSF of PD patients, without an apparent clinical counterpart. PLoS One, 9(7): p. e101763.

7. Zarei, M., et al. (2013), Cortical thinning is associated with disease stages and dementia in Parkinson's disease. J Neurol Neurosurg Psychiatry,84(8): p. 875-81.

8. Wilson, H., et al.(2019), Cortical thinning across Parkinson's disease stages and clinical correlates. J Neurol Sci, 398: p. 31-38.

\title{
KẾT QUẢ SẢN KHOA Ở THAI PHỤ ĐÁI THÁO ĐƯờNG THAI KỲ ĐÊ ĐỦ THÁNG TẠI BỆNH VIỆN PHỤ SẢN TRUNG ƯO'NG
}

\section{TÓM TẮT}

Muc tiêu: nhân xét kết quả sản khoa ở thai phu đái tháo đường thai kỳ đẻ đủ tháng tại Bệnh viện Phụ sản Trung ương năm 2019-2020.Kêt quả: tỷ lệ bệnh nhân ĐTĐTK mổ đẻ $(78,29 \%)$ cao hơn so với tỷ lệ đẻ thường. Các nguyên nhân ĐTĐTK đẻ mổ thường gặp là do nguyên nhân có tiền sử mổ cũ $(32,03 \%)$, nguyên nhân do thai to chiếm 14,84\%.Cân nặng sơ

\footnotetext{
*Trường Đại học Y Hà Nọi

Chịu trách nhiệm chính: Nguyễn Mạnh Thắng

Email: bsnguyenmanhthang@gmail.com

Ngày nhận bài: 8.3.2021

Ngày phản biên khoa học: 29.4.2021

Ngày duyệt bài: 11.5.2021
}

Nguyễn Mạnh Thắng* sinh trung bình của nhóm thai phụ ĐTĐTK đẻ đủ tháng là $3433 \pm 442 \mathrm{~g}$. Có 12 trẻ có cân năng từ $4000 \mathrm{~g}$ trở lên, chiếm $7,05 \%$. Phần lớn trẻ sinh ra có me bị ĐTĐTK không có biến chứng sau đẻ, chiếm tỷ lê $81,64 \%$. Có 4 trẻ bị hạ glucose máu $(2,35 \%), 22$ trẻ có bị vàng da sau sinh $(12,94 \%)$. Tỷ lệ trẻ sơ sinh có chỉ số Apgar sau 1 phút và sau 5 phút $<7$ điểm chiếm tỷ lệ thấp (lần lượt là 2,94\% và 1,18\%). Kết luận: thai phụ ĐTĐTK có tỷ lệ mổ đẻ cao. Biến chứng ở trẻ sinh ra có me bị ĐTĐTK thường gặp là vàng da sau sinh, biến chứng ít gặp hơn là hạ glucose máu và suy hô hấp sau sinh.

Tư khoá: kết quả sản khoa, đái tháo đường thai kỳ, hạ đường máu, suy hô hấp sau sinh, vành da sau sinh.

\section{SUMMARY \\ MATERNAL AND FETAL OUTCOME IN}




\section{GESTATIONAL DIABETES MELLTTUS (GDM) WITH FULL-TERM PREGNANCY IN NATIONAL HOSPITAL OF OBSTETRICS \& GYNECOLOGY}

Objective: To describe maternal and fetal outcome in Gestational Diabetes Mellitus (GDM) with full-term pregnancy in National Hospital of Obstetrics \& Gynecology during the period from 2019 to 2020. Results: The rate of Caesarean section among women with GDM $(78,29 \%)$ was higher compared to vaginal delivery. The common reasons for Caesarean section in GDM were previous caesarean section $(32,03 \%)$ and fetal macrosomia (14,84\%). The average birthweight of women with GDM was $3433+$ 442g. There were 12 newborns with a birthweight $4000 \mathrm{~g}$ or more, accounting for $7,05 \%$. The majority of newborns in GDM group $(81,64 \%)$ had no postpartum complications. There were 4 cases of neonatal hypoglycemia (2.35\%) and 22 cases of newborn jaundice $(12.94 \%)$. The prevalence of newborns with Apgar score at 1 minute and 5 minutes $<7$ were low $(2,94 \%$ and $1,18 \%$, respectively). Conclusions: Women with GDM had a high rate of Caesarean section. The most common postpartum complication in GDM group was newborn jaundice, meanwhile the less common complications were neonatal hypoglycemia and newborn respiratory distress syndrome.

Key words: maternal and fetal outcome, Gestational Diabetes Mellitus, hypoglycemia, newborn respiratory distress syndrome, newborn jaundice.

\section{I. ĐĂT VẤN ĐỀ}

Đái tháo đường thai kỳ (ĐTĐTK) là bênh rối loạn chuyển hoá hay gặp trong qua trình mang thai. Tỷ lê ĐTĐTK ngày càng tăng, đặc biệt ở các nước phát triển. Hiện nay, tỷ lệ này cũng có xu hướng tăng nhanh ở Việt Nam [1]. Viêt Nam là nước nằm trong vùng có nguy cơ mắc ĐTĐTK cao. Tỷ lệ ĐTĐTK ở nước ta dao động từ 3,6 $39 \%$, thay đổi tuỳ theo vùng miền.

ĐTĐTK làm tăng nguy cơ các biến cố sản khoa ở thai phụ, đặc biệt như làm tăng tỷ lệ sảy thai, thai chế lưu, ngật sơ sinh, tăng nguy cơ tiền sản giật, sản giật. Trẻ sơ sinh của những bà me bị ĐTĐTK có nguy cơ cao bị hạ đường máu, vàng da và nguy cơ bị béo phì, đái tháo đường [2].

Nhiều công trình nghiên cứu về ĐTĐTK đã được thực hiện, nhờ đó những hiểu biết về bệnh và việc kiểm soát bệnh càng ngày càng đạt được hiệu quả tốt. Các kết quả nghiên cứu ở Việt Nam cho thây tỷ lệ mắc bệnh ngày càng tăng, tỉ lệ thai phụ điêu trị quản lí và điều trị ĐTĐTK ngày càng phức tapp.

Triển khai tầm soát và xác định tỷ lệ ĐTĐTK, tìm kiếm các giải pháp theo dõi, quản lý thai nghén với thai phụ mắc ĐTĐTK, sự chia sẻ thông tin giữa bác sĩ nội tiết, bác sĩ sản khoa, các cơ sở quản lý thai nghén và thai phụ là rất cần thiết trong tình hình hiện tại. Câu hỏi nghiên cứu mà chúng tôi đă̆t ra là: Tỷ lệ mổ đẻ, đẻ thường của thai phụ đái tháo đường đẻ đủ tháng ở Bênh viên Phu sản Trung Ương phân bố như thế nào? Có yếu tố nguy cơ nào đặc trưng? Kết quả sản khoa liên quan tới sơ sinh ra làm sao? Cách tư vấn điều trị, quản lý, theo dõi thai nghén như thế nào là phù hợp nhất nhằm đưa lại kết quả thai nghén tốt nhất cho sản phụ và gia đình? Chính vì vậy, nghiên cứu được thực hiên với muc tiêu nhẩn xét kết quả sản khoa ở thai phu đái tháo đường thai kỳ đẻ đủ tháng tai Bệnh viện Phụ sản Trung ương năm 2019-2020.

\section{II. ĐỐI TƯỢNG VÀ PHƯƠNG PHÁP NGHIÊN CỨU}

2.1. Đối tượng nghiên cứu.

2.1.1. Tiêu chuẩn lựa chọn. Thai phụ được được chẩn đoán ĐTĐTKđđến điều trị và đẻ đủ tháng tại Bệnh viện Phụ sản Trung ương từ tháng $7 / 2019$ đến tháng $7 / 2020$. Đơn thai, tuổi thai từ 37 tuân 01 ngày đến 41 tuần 6 ngày. Có hồ sơ me và sơ sinh được ghi chép đầy đủ rõ ràng về hành chính,chuyên môn, xét nghiệm trước và sau khi đẻ

2.1.2. Tiêu chuẩn loại trừ. Thai phụ đã được chẩn đoán ĐTĐ trước khi có thai.Thai phụ đang mắc các bệnh có ảnh hưởng đến chuyển hóa glucose như Basedow, suy giáp, Cushing, suy gan, suy thân....

2.2. Phương pháp nghiên cứu.

2.2.1. Thiết kế nghiên cứu:nghiên cứu mô tả và tiến cứu

\subsubsection{Cỡ mẫu nghiên cứu}

Dựa theo công thức tính cõ mẫu:

$$
\mathrm{n}=\frac{\mathrm{Z}^{2}{ }_{1-\mathrm{a} / 2 \cdot \mathrm{p} \cdot(1-\mathrm{p})}}{\mathrm{d}^{2}}
$$

Trong đó: n: số thai phụ

$Z_{\text {1-a/2 }}$ : độ tin cậy $95 \%$ khi $a=0,05$ thì $Z_{\text {1-a/2 }}$ $=1,96$.

$\mathrm{p}=0,11$ là tỷ lệ ĐTĐTK ở nghiên cứu của Nguyễn Lê Hươngnăm 2014[3].

$\mathrm{d}=0,05=$ sai số tương đối.

Tính theo công thức: $\mathrm{n}=150$ thai phụ,chúng tôi lấy cõ̃ mẫu là 170 .

\subsubsection{Các biến số nghiên cứu chính}

- Kết quả theo dõi điều trị ĐTĐTK:

+ Cách thức điêu tri

- Kết quả sản khoa:

+ Tiên sản giật, sản giật, đa ối

+ Suy thai mạn tính, suy thai trong chuyển da

+ Đẻ khó: mổ đẻ, rách đường sinh dục, chảy máu sau đẻ.

+ Thai to, ngạt sơ sinh (chỉ số Apgar), hạ 
đường huyết sơ sinh, vàng da

+ Dị tât bẩm sinh, tử vong sơ sinh

+ Nhiểm khuẩn sau đẻ

\subsubsection{Một số tiêu chuẩn liên quan trong nghiên cứu}

Tiền sản giật: khi thai phụ có dấu hiệu tăng huyết áp (huyết áp tối đa $\geq 140 \mathrm{mmHg}$ và/ hoặc huyết áp tối thiểu $\geq 90 \mathrm{mmHg}$, hoặc so với huyết áp trước khi có thai, nếu huyết áp tối đa tăng $\geq 30 \mathrm{mmHg}$ và/ hoặc huyết áp tối thiểu tăng $\geq 15 \mathrm{mmHg})$, phù, protein niệu $(\geq 0,5 \mathrm{~g} /$ lít ở mẫu nước tiểu ngẫu nhiên, $\geq 0,3 \mathrm{~g} / \mathrm{l}$ ở mấu nước tiểu 24 giờ).

Thai già tháng: là thai ở trong tử cung quá 287 ngày (hết 41 tuần) tính từ ngày đầu của kỳ kinh cuối cùng.

Đa ối: khi chỉ số ối > 24cm gọi là đa ối. Chỉ số ối là tổng của bốn số đo chiều sâu của bốn túi ối lớn nhất đo ở bốn góc trên thành bụng của người mẹ, đo theo phương thẳng đứng.

Ngạt sơ sinh: Dựa vào chỉ số Apgar: tổng điểm 5 nội dung (bảng 1)

Bảng 1. Chỉ số Apgar

\begin{tabular}{|c|c|c|c|}
\hline Nội dung & 2 điếm & $\mathbf{1}$ điếm & 0 điếm \\
\hline Nhịp tim & $\begin{array}{c}\text { >100 lần } \\
\text { /phút }\end{array}$ & $\begin{array}{c}<100 \text { lần } \\
\text { /phút }\end{array}$ & Không có \\
\hline Hô hấp & khóc to & $\begin{array}{c}\text { Thớ yếu, } \\
\text { khóc yếu }\end{array}$ & Không thở \\
\hline $\begin{array}{c}\text { Trương } \\
\text { lực cơ }\end{array}$ & ++ & + & Không \\
\hline Phản xạ & ++ & + & Không \\
\hline Màu da & $\begin{array}{c}\text { Hồng toàn } \\
\text { thân }\end{array}$ & $\begin{array}{c}\text { Tím đầu chi } \\
\text { quanh môi }\end{array}$ & $\begin{array}{c}\text { Tím tái toàn } \\
\text { thân hoặc } \\
\text { trắng }\end{array}$ \\
\hline
\end{tabular}

Bình thường, Apgar phút thứ nhất sau đẻ $\geq 7$ điểm, trẻ không cần hồi sức. Nếu Apgar $<7$ điểm: trẻ ngạt.

Hạ đường huyết sơ sinh: là khi glucose máu trẻ $\leq 2.6 \mathrm{mmol} / \mathrm{l}$ (Xét nghiệm glucose máu ngay sau đẻ và bất cứ thời điểm nào trẻ có dấu hiệu hạ glucose máu trong 3 ngày sau đẻ).

Thai suy dinh dưỡng: Cân nặng lúc sinh đủ tháng $<2500 \mathrm{gr}$

Thai to:Ở Việt Nam, đối với con so: thai $\geq$ $3500 \mathrm{~g}$ được coi là thai to, đối với con rạ: thai $\geq$ $3800 \mathrm{~g}$ được coi là thai to.

- Chết chu sinh: Hiện tượng tử vong thai nhi và sơ sinh từ trước, trong và sau đẻ bảy ngày có tuổi thai từ tuần 22 , chiều dài từ $25 \mathrm{~cm}$ và cân nặng từ $500 \mathrm{~g}$ khi đẻ trở lên

2.3. Phân tích số liệu: Sử dụng các test thống kê y học

Các biến số rời rạc được mô tả theo tỷ lệ phân trăm, khi so sánh các biến số rời rạc sử dụng thuật toán $\chi^{2}$. Các biến liên tục được mô tả dưới dạng trị số trung bình, cộng trừ phương sai và khi so sánh sử dụng thuật toán test $T$ student.Tỷ xuất chênh Odds radio: OR và khoản tin cậy 95\%CI: với khoảng tin cậy chứa giá trị 1 tương quan không có ý nghĩa thổng kê. Kết quả so sánh khác nhau có ý nghĩa thống kê khi $p<0,05$.

2.4. Đạo đức của nghiên cứu. Đề tài nghiên cứu được thông qua Hội đồng đạo đức của Bệnh viện Phụ sản Trung Ương.Thổng tin của bệnh nhẩn sẽ được bảo mật và chỉ được sử dụng cho nghiên cứu.Tất cả các bệnh nhân tham gia nghiên cứu đều được giải thích rõ ràng về mục tiêu nghiên cứu và đồng ý tham gia nghiên cứu.

\section{KẾT QUẢ NGHIÊN CứU}

Trong khoảng thời gian từ tháng 7/2019 đến tháng 7/2020, tại Bệnh viện Phụ sản Trung Ương, chúng tôi tiến hành nghiên cứu được 170 bệnh nhân đẻ đủ tháng bị đái tháo đường thai kỳ phù hợp với tiêu chuẩn nghiên cứu. Thai phụ ĐTĐTK ở nhóm tuổi25 - 29 chiếm tỷ lệ lớn nhất với 60 bệnh nhân, chiếm 35,3\%, nhóm $\leq 24$ tuổi chiếm tỷ lệ thấp nhất với chỉ 2,4\%. Độ tuổi trung bình của nhóm bệnh nhân ĐTĐTK là 32,05 \pm 4,89, tuổi nhỏ nhất là 20 tuổi và độ tuổi lớn nhất là 43 tuổi. Phần lớn bệnh nhân ĐTĐTK sống ở thành thị chiếm $75,29 \%$. Thai phụ là công chức, viên chức chiếm tỷ lệ cao nhất với 30,59\%.

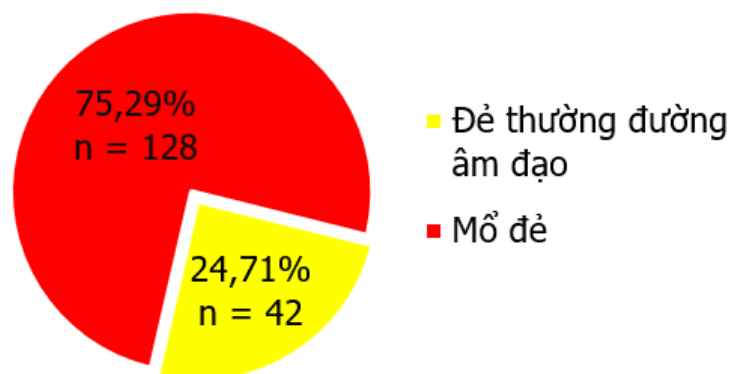

Biểu đồ 1. Phương pháp đẻ của bệnh nhân ÐTÐTK

Nhân xét: Phần lớn bênh nhân ĐTĐTK sinh bằng hình thức mổ đẻ lấy thai, chiếm tỷ lệ 78,29\%. Chỉ 24,71\% bệnh nhân đẻ thường đường âm đạo.

Bảng 1. Lý do mồ lấy thai của bệnh nhân ÐTÐTK

\begin{tabular}{|c|c|c|}
\hline Lý do mố đẻ & $\mathbf{n}$ & $\mathbf{\%}$ \\
\hline Mố cũ & 41 & $32,03 \%$ \\
\hline Thai to & 19 & $14,84 \%$ \\
\hline Ngôi bất thường & 9 & $7,03 \%$ \\
\hline Suy thai & 6 & $4,69 \%$ \\
\hline Chuyển dạ kéo dài & 12 & $9,38 \%$ \\
\hline Tiền sản giật/Sản giật & 5 & $3,91 \%$ \\
\hline
\end{tabular}




\begin{tabular}{|c|c|c|}
\hline $\begin{array}{c}\text { Do bệnh lý của mẹ, } \\
\text { me thấp, mẹ lớn tuổi }\end{array}$ & 8 & $6,25 \%$ \\
\hline $\begin{array}{c}\text { Lý do xã hội: IVF, tiền } \\
\text { sử sản khoa nặng nề }\end{array}$ & 28 & $21,87 \%$ \\
\hline Tống & $\mathbf{1 2 8}$ & $\mathbf{1 0 0 \%}$ \\
\hline
\end{tabular}

Nhân xét: Trong số 128 bệnh nhân ĐTĐTK sinh bằng hình thức mổ đẻ: Mổ đẻ do nguyên nhân có mổ cũ chiếm tỷ lệ cao nhất với 41 trường hợp, chiếm 32,03\%. Có 19 trường hợp mổ đẻ do tiên lượng thai to, chiếm 14,84\%. Nguyên nhân mổ đẻ do kèm theo tiên sản giật/sản giật chiếm tỷ lệ thấp nhất với chỉ 5 trường hợp, chiếm 3,91\%.

Bảng 2. Liên quan giữa phương pháp đîêu trị và kêt cục thai ky்.

\begin{tabular}{|c|c|c|c|c|}
\hline \multirow{2}{*}{\multicolumn{2}{|c|}{$\begin{array}{c}\text { Phương } \\
\text { pháp điểu } \\
\text { tri }\end{array}$}} & \multicolumn{2}{|c|}{ Kết quả thai kỳ } & \multirow[b]{2}{*}{$\mathbf{p}$} \\
\hline & & Mổ đẻ & $\begin{array}{c}\text { Đẻ } \\
\text { thường }\end{array}$ & \\
\hline \multirow{2}{*}{$\begin{array}{c}\text { Điều } \\
\text { chỉnh } \\
\text { chế độ } \\
\text { ăn }\end{array}$} & $\mathrm{n}$ & 86 & 29 & \multirow{4}{*}{$\begin{array}{c}p= \\
0,492 \\
\text { OR }= \\
0,918 \\
95 \% C I \\
(0,279- \\
2,460)\end{array}$} \\
\hline & $\%$ & $74,78 \%$ & $25,22 \%$ & \\
\hline \multirow{2}{*}{$\begin{array}{c}\text { Điêu trị } \\
\text { bằng } \\
\text { insulin }\end{array}$} & $\mathrm{n}$ & 42 & 13 & \\
\hline & $\%$ & $76,36 \%$ & $23,64 \%$ & \\
\hline
\end{tabular}

Nhân xét: Trong số 128 bệnh nhân ĐTĐTK sinh bẳng hình thức mổ đẻ: tỷ lệ mổ đẻ trong nhóm bệnh nhân điêu trị bằng insulin cao hơn với 76,36\%. Tuy nhiên sự khác biệt về kết cục thai kỳ giữa 2 nhóm phương pháp điều trị không có ý nghĩa thống kê với giá trị $\mathrm{p}>0,05$ và $\mathrm{OR}=$ 0,918 với khoảng tin cậy $95 \% \mathrm{CI}(0,279-2,460)$.

Bảng 3. Phân nhóm cân nặng sơ sinh ngay sau đé

\begin{tabular}{|c|c|c|}
\hline Cân nặng sơ sinh(g) & $\mathbf{n}$ & $\mathbf{\%}$ \\
\hline$<2500$ & 6 & $3,53 \%$ \\
\hline 2500 đến $<3000$ & 48 & $28,24 \%$ \\
\hline 3000 đến < 3500 & 76 & $44,71 \%$ \\
\hline 3500 đến < 4000 & 28 & $16,47 \%$ \\
\hline$\geq 4000$ & 12 & $7,05 \%$ \\
\hline Trung bình & \multicolumn{2}{|c|}{$3433 \pm 442$} \\
\hline Trẻ nhẹ cân nhất & \multicolumn{2}{|c|}{2200} \\
\hline Trẻ nặng cân nhất & \multicolumn{2}{|c|}{4600} \\
\hline Tống & $\mathbf{1 7 0}$ & $\mathbf{1 0 0} \%$ \\
\hline
\end{tabular}

Nhânn xét: Cân nặng sơ sinh trung bình của nhóm thai phụ ĐTĐTKK đẻ đủ tháng là $3433 \pm$ $442 \mathrm{~g}$, trẻ có cấn nặng nhẹ nhất là $2200 \mathrm{~g}$ và trẻ có cân nặng lớn nhất là $4600 \mathrm{~g}$. Nhóm trẻ sơ sinh có cân nặng từ $3000 \mathrm{~g}$ đến $3500 \mathrm{~g}$ có tỷ lệ cao nhất với 76 trẻ, chiếm 44,71\%. Có 12 trẻ có cân nặng từ $4000 \mathrm{~g}$ trở lên, chiếm 7,05\%. Có 6 trẻ có cẩn nặng lúc sinh ở mức suy dinh dưỡng nhỏ hơn $2500 \mathrm{~g}$ lúc sinh, chiếm 3,53\%.

Bảng 4. Chỉ sốApgar cúa trẻ sơ sinh sau đẻ

\begin{tabular}{|c|c|c|c|c|}
\hline \multirow{2}{*}{$\begin{array}{c}\text { Chỉ số } \\
\text { Apgar } \\
\text { (điểm) }\end{array}$} & \multicolumn{2}{|c|}{ Phút thứ 1 } & \multicolumn{2}{c|}{ Phút thứ 5 } \\
\cline { 2 - 5 } & $\mathbf{n}$ & $\mathbf{\%}$ & $\mathbf{n}$ & $\mathbf{\%}$ \\
\hline$<7$ & 5 & $2,94 \%$ & 2 & $1,18 \%$ \\
\hline$\geq 7$ & 165 & $97,06 \%$ & 168 & $98,82 \%$ \\
\hline Tống & $\mathbf{1 7 0}$ & $\mathbf{1 0 0} \%$ & $\mathbf{1 7 0}$ & $\mathbf{1 0 0} \%$ \\
\hline
\end{tabular}

Nhân xét: Trong 170 trẻ sinh ra từ các bà me bị ĐTĐTK, chỉ có 2 trẻ có chỉ số Apgar sau 5 phút < 7 điểm, chiếm tỷ lệ 1,18\%. Có 168 trẻ sinh ra có chỉ số Apgar trong giới hạn bình thường.

Bảng 5. Biến chứng của tré sơ sinh sau đẻ của bệnh nhân ĐTĐTK

\begin{tabular}{|c|c|c|}
\hline Biến chứng & $\mathbf{n}$ & $\mathbf{0}$ \\
\hline Bình thường & 139 & $81,64 \%$ \\
\hline Hạ Glucose máu & 4 & $2,35 \%$ \\
\hline Suy hô hấp & 5 & $2,94 \%$ \\
\hline Vàng da & 22 & $12,94 \%$ \\
\hline Tứ vong chu sinh & 0 & $0 \%$ \\
\hline Tống & $\mathbf{1 7 0}$ & $\mathbf{1 0 0} \%$ \\
\hline
\end{tabular}

Nhân xét: Phân lớn trẻ sinh ra có mẹ bị ĐTĐTK không có biến chứng gì sau đẻ, với 139 trẻ, chiếm tỷ lệ $81,64 \%$. Có 4 trẻ bị hạ glucose máu $(2,35 \%), 5$ trẻ bi suy hô hấp sau sinh $(2,94 \%)$ và 22 trẻ có bị vàng da sau sinh $(12,94 \%)$. Không có trẻ nào tử vong trong giai đoạn chu sinh.

\section{BÀN LUẬN}

Kết quả nghiên cứu cho thây, phân lớn bệnh nhân ĐTĐTK sinh bằng hình thức mổ lấy thai, chiếm tỷ lệ 78,29\%. Lý do sinh bằng hình thức mổ đẻ bao gồmmổ do nguyên nhân có mổ cũ chiếm tỷ lệ cao nhất với 41 trường hợp, chiếm $32,03 \%$. Nguyên nhân do thai to có 19 trường hợp, chiếm 14,84\%. Theo Lê Thị Thanh Tâm (2016) trong 127 trường hợp ĐTĐTK mổ đẻ thì nguyên nhân nhiều nhất là thai to với 30 trường hợp chiếm 23,6\%; 12 ca vì tiền sản giật chiếm 9,4\%, trong đó có 1 trường hợp bị sản giật; mổ đẻ vì mổ đẻ cũ chiếm 17,3\%; 16 ca được chỉ định mổ đẻ vì ngôi thai không tiến triển, đâu không lọt chiếm tỷ lệ $12,6 \%$; 2 ca vì thai suy chiếm 1,6\%[4]. Theo nghiên cứu HAPO trên 23316 thai phụ đái tháo đường thai kỳ được điêu trị của 15 trung tâm tại 9 quốc gia cho thấy tỷ lệ mổ đẻ là $23,7 \%$, trong đó tỷ lệ mổ lân đâu là $16 \%$ còn lại $7,7 \%$ là do mổ cũ[5]. Chỉ định mổ đẻ cho các thai phụ đái tháo đường thai kỳ chỉ đặt ra khi dự kiến cân nặng của con to $>4000 \mathrm{~g}$. Nếu glucose máu của các thai phụ đái tháo đường thai kỳ được kiểm soát tốt thì chỉ định mổ đẻ bắt buộc là hoàn toàn không có cơ sở.

Trong 2 phương pháp điều trị ĐTĐTK là điểu chỉnh chế độ ăn và điêuu trị bằng thuốc insulin, nhóm bệnh nhân điều trị bằng insulin chiếm tỷ lệ 
kết thúc thai kỳ bằng hình thức mổ đẻ cao hơn, với $76,36 \%$. Tuy nhiên sự khác biệt về kết cục thai kỳ giữa 2 nhóm phương phá điêu trị không có ý nghĩa thống kê với $\mathrm{OR}=0,918$ và khoảng tin cậy $95 \%$ CI $(0,279-2,460)$. So với nhóm điêu trị phối hợp insulin thì điều trị bằng chế độ ăn và luyện tập dễ dàng hơn. Điều này cho thấy việc sàng lọc sớm, phát hiện sớm những trường hợp ĐTĐTK nhẹ, đường huyết tăng vừa phải, để có sự điều chỉnh chế độ ăn và luyện tập kịp thời, kiểm soát đường huyết tốt, không những tránh cho bệnh nhân phải điều trị bằng tiêm insulin rất phức tạp mà còn giảm tỷ lệ tai biến trong sản khoa.

Cân nặng sơ sinh trung bình của nhóm thai phụ ĐTĐTKK đẻ đủ tháng là $3433 \pm 442 \mathrm{~g}$, trẻ có cân nặng nhe nhất là $2200 \mathrm{~g}$ và trẻ có cân nặng lớn nhất là $4600 \mathrm{~g}$. Nhóm trẻ sơ sinh có cân nặng từ $3000 \mathrm{~g}$ đến $3500 \mathrm{~g}$ có tỷ lệ cao nhất với 76 trẻ, chiếm $44,71 \%$. Có 12 trẻ có cân nặng từ $4000 \mathrm{~g}$ trở lên, chiếm 7,05\%. Cân nặng trung bình của trẻ sơ sinh lúc đẻ trong nghiên cứu của chúng tôi tương tự như nghiên cứu của tác giả Lê Thị Thanh Tâm là $3400 \pm 600 \mathrm{~g}[6]$. Theo nghiên cứu của Vũ Bích Nga thì cân nặng trung bình trẻ sơ sinh lúc đẻ của nhóm sản phụ ĐTĐTK là $3,2 \pm$ $0,6 \mathrm{~kg}$, thấp nhất là $1,2 \mathrm{~kg}$, cao nhất là $4,8 \mathrm{~kg}$ [7]. Nghiên cứu của Langer và cộng sự, cân nặng trung bình trẻ sơ sinh của sản phụ ĐTĐTK được điêu trị là $3,3 \pm 0,5 \mathrm{~kg}$, tương tự trẻ sơ sinh của các bà me không mắc ĐTĐTK. Theo Crowther và công sứ, khi so sánh kết quả của 490 thai phu ĐTĐTK được kiểm soát và điều trị và 510 thai phụ không được chăm sóc thường quy thì ở những thai phụ ĐTĐTK nếu kiểm soát tốt glucose máu me làm giảm cân năng trung bình lúc sinh một cách có ý nghĩa [8].Tỷ lệ sản phụ có cân nặng trẻ lúc sinh từ $4000 \mathrm{~g}$ trở lên trong nghiên cứu của chúng tôi cũng thấp hơn tác giả Lê Thị Thanh Tâm: 45 trên 308 trẻ có cân nặng từ $4000 \mathrm{~g}$ trở lên, chiếm 14,6\% [4]. Theo Jane và cộng sự, tỷ lệ thai to ở nhóm thai phụ không ĐTÐTK là 11,76\%, trong nhóm ĐTĐTK 16,9\% (93/505) [9]. Nghiên cứu của tác giả Lê Thanh Tùng cho thây tỷ lệ thai to $>4000 \mathrm{~g}$ trong nhóm ĐTÐTK là $12,0 \%$ trong khi ở nhóm không ĐTĐTK chỉ chiếm 2,9\%. Thai to tâp trung tại một số bộ phận như vai, ngực, cánh tay, bụng, đừi và má. Siểu âm trước sinh dựa vào đo kích thước vòng bung, độ dày mồ mềm ở vai $(>12 \mathrm{~mm})$ có giá trị hơn là đo đường kính lưỡng đỉnh và chiêu dài xương đùi. Thai to ở bà mẹ ĐTĐTK là một biến chứng thường gặp, gây nhiều nguy cơ trong cuộc đẻ, như tăng tỷ lệ mổ đẻ, cắt rộng hoặc rách tầng sinh môn, ngạt sơ sinh,... Điều tri kiểm soát đường huyết tốt làm giảm đáng kể tỉ lệ thai to. Do vậy, cần tư vấn cho thai phụ ĐTĐTK tuân thủ chặt chẽ chế độ ăn và luyên tập, theo dõi đường huyết hàng ngày và định kỳ hàng tháng siêu âm đánh giá sự phát triển cân nặng của thai, để đảm bảo kết quả thai nghén tốt nhất cho cả me và con.

Trong 170 trẻ sinh ra từ các bà me bị ĐTĐTK, chỉ có 2 trẻ có chỉ số Apgar sau 5 phút $<7$ điểm, chiếm tỷ lệ $1,18 \%$. Có 168 trẻ sinh ra có chỉ số Apgar trong giới hạn bình thường.Có 4 trẻ sơ sinh bị hạ glucose máu chiếm tỷ lệ 2,35\%, 5 trẻ bi suy hô hấp sau sinh chiếm tỷ lể 2,94\% và 22 trẻ có bị vàng da sau sinh chiếm tỷ lệ $12,94 \%$. Tổng số trẻ có biến chứng chiếm 18,36\%. Không có trẻ nào tử vong trong giai đoan chu sinh. Theo Jane, tỷ lệ hạ đường huyết trên lâm sàng ở trẻ sơ sinh trong nhóm không ĐTĐTK là 0,7\%, trong nhóm ĐTĐTK là 5,8\%; tỷ lệ vàng da sơ sinh có yêu cầu chiếu đèn trong nhóm không ĐTĐTK là 3,0\%; trong nhóm ĐTĐTK là 4,2\% [9]. Nghiên cứu hồi cứu của Nguyễn Thế Bách, tư vong chu sinh là $8,6 \%$, ha đường huyết sơ sinh 20,6\%; cao hơn của chúng tôi, có thể do đây là nghiên cứu hồi cứu nên việc theo dõi kiểm soát đường huyết không đạt mục tiêu, nên ảnh hưởng của tăng đường máu đến thai nhi rõ rệt hơn. Nghiên cứu của Vũ Bích Nga cho thây tỷ lệ dị tật bẩm sinh chiếm 2,9\%, hạ đường huyết sớ sinh là 4,9\% [7]. Tỷ lệ hạ đường huyết sơ sinh theo Nguyễn Thị Lệ Thu là 4,61\%.

\section{KẾT LUÂN}

Kết quả nghiên cứu cho thấy, tỷ lệ bệnh nhân ĐTĐTK mổ đẻ $(78,29 \%)$ cao hơn so với tỷ lệ đẻ thường. Các nguyên nhân ĐTĐTK đẻ mổ thường gặp là do nguyên nhân có tiền sử mổ cũ $(32,03 \%)$, nguyên nhân do thai to chiếm $14,84 \%$. Tỷ lệ đẻ mổở nhóm bệnh nhân điều trị bằng insulin chiếm tỷ lệ cao với $76,36 \%$, tuy nhiên không có sự khác biệt giữa 2 nhóm phương pháp điều trị.

Cân nặng sơ sinh trung bình của nhóm thai phụ ĐTĐTंK đẻ đủ tháng là $3433 \pm 442 \mathrm{~g}$, trẻ có cân nặng nhe nhất là $2200 \mathrm{~g}$ và trẻ có cân nặng lớn nhất là $4600 \mathrm{~g}$. Có 12 trẻ có cân nặng từ $4000 \mathrm{~g}$ trở lên, chiếm 7,05\%. Phần lớn trẻ sinh ra có mẹ bị ĐTĐTK không có biến chứng sau đẻ, với 139 trẻ, chiếm tỷ lệ $81,64 \%$. Có 4 trẻ bị hạ glucose máu $(2,35 \%), 22$ trẻ có bi vàng da sau sinh $(12,94 \%)$, không có trẻ nào tử vong trong giai đoạn chu sinh. Tỷ lệ trẻ sơ sinh có chỉ số Apgar sau 1 phút và sau 5 phút $<7$ điểm chiếm tỷ lệ thấp (lần lượt là $2,94 \%$ và $1,18 \%$ ). 


\section{TÀI LIÊU THAM KHẢO}

1. Alberti KGMM, Zimmet PZ. Definition, diagnosis and classification of diabetes mellitus and its complications. Part 1: diagnosis and classification of diabetes mellitus. Provisional report of a WHO Consultation. Diabetic Medicine. 1998;15(7):539-553.

2. Hartling $L$, Dryden DM, Guthrie $A$, et al. Screening and Diagnosing Gestational Diabetes Mellitus. Agency for Healthcare Research and Quality (US); 2012.

3. Nguyến Lế Hương, Đỗ Quan Hà. Tỷ lệ đái tháo đường thai nghén tại khoa Khám theo yêu câu, Bênh viện Phụ Sản Trung Ương năm 2012 và một sổ yếu tố nguy cơ. Tạp chí Phụ Sản. 2014;12(2):108-111.

4. Lê Thi Thanh Tâm. Nghiên Cứu Phân Bố Một Số Yếu Tổ Liên Quan và Kểt Quả Sản Khoa ở Thai Phu Đái Tháo Đường Thai Kỳ Tại Thành Phố Vinh. Luận Án Tiến sỹ Y Học.; 2017.

5. HAPO Study Cooperative Research Group,
Metzger BE, Lowe LP, et al. Hyperglycemia and adverse pregnancy outcomes. N Engl J Med. 2008;358(19):1991-2002.

6. Lê Thi Thanh Tâm, Đặng Thị Minh Nguyêt, Nguyển Cảnh Phú. Nhận xét kết quả xét nghiếm sàng loc bênh đái tháo đường thai kỳ tai thành phố Vinh, Nghệ An. Tạp chí $Y$ học thực hành. 2016:997(2/2016):124-126.

7. Vũ Bích Nga. Nghiên Cứu Ngưỡng Glucose Máu Lúc Đói Để Sàng Loc Đái Tháo Đướng Thai Kỳ và Bước Đầu Đánh Giá Hiệu Quả Điều Trị. Luận án Tiến sĩ Y Học, Trường Đại Học Y Hà Nội.; 2009.

8. Crowther CA, Hiller JE, Moss JR, et al. Effect of treatment of gestational diabetes mellitus on pregnancy outcomes. N Engl J Med. 2005;352(24):2477-2486.

9. Hirst JE, Tran TS, Do MAT, Morris JM, Jeffery HE. Consequences of gestational diabetes in an urban hospital in Viet Nam: a prospective cohort study. PLoS Med. 2012;9(7):e1001272.

\section{THỰC TRANG TIẾNG ÔN VÀ THỰC HÀNH PHÒNG NGỪA ĐIẾC NGHỀ NGHIÊPP CỦA NGƯỜI LAO ĐÔ̂NG TẠI NHÀ MÁY TINH BộT SẮN ĐỒNG XUÂN, PHÚ YÊN, 2018}

\section{TÓM TẮT}

Một trong những bệnh nghề nghiệp có xu hướng ngày càng gia tăng tỷ lệ thuận theo tốc độ hiện đại hóa - công nghiệp hóa của xã hội hiện nay là bệnh điếc nghề nghiệp. Hầu hết các quy trình sản xuất đều phát ra tiếng ồn, tuy nhiên, một số ngành nghề đặc thù có mức ồn cao tập trung chủ yếu ở các ngành sản xuất công nghiệp, in ấn, xay xát và chế biến thực phẩm. Nghiên cứu đã đước tiến hành với muc đích tìm hiểu mức độ ô nhiễm tiếng ồn tại nhà máy và thực hành của người lao động tai đây trong viêc phòng ngừa điếc nghề nghiệp. Nghiên cứu mô tả cắt ngang đã được tiến hành khảo sát trên 125 công nhân tham gia lao động trực tiếp tại nhà máy. Thực hiện quan trắc tổng số mấu về tiếng ôn là 64 , trong đó tiếng ôn chung là 40 mẫu và tiếng ôn theo dải tần là 24 mẫu. Kết quả nghiên cứu cho thây có $53,9 \%$ mấu tiếng ôn vượt giới hạn cho phép; cường độ tiếng ồn chung tại nhà máy dao động trong khoảng $74-93$ dBA; khu vực phát ra tiếng ồn cao nhất là khu vực phân ly với mức ồn trung bình là $91 \pm 1,83$ dBA.Tuy nhiên, chỉ có $52,8 \%$ người lao động có thực hành đúng trong việc phòng ngữa điếc nghề nghiệp. Đáng lưu ý là chỉ có 44\% người lao động sử dụng thiết bị bảo hộ lao động

\footnotetext{
${ }^{1}$ Trường Đại học Y tế công cộng

${ }^{2}$ Trung tâm kiểm soát bệnh tật tỉnh Phú Yên

Chịu trách nhiệm chính: Nguyễn Ngọc Bích

Email: nnb@huph.edu.vn

Ngày nhận bài: 9.3.2021

Ngày phản biên khoa hoc: 28.4.2021

Ngày duyệt bài: 12.5 .2021
}

\section{Nguyễn Ngọc Bích ${ }^{1}$, Phan Thị Lan Phương ${ }^{2}$}

một cách thường xuyên khi tiếp xúc với nguồn ồn và chỉ có $31,5 \%$ công nhân đeo thiết bị bảo vệ tai đúng cách khi làm việc. Nghiên cứu khuyến nghị nhà máy áp dụng các giải pháp giảm thiểu tiếng ồn nơi làm việc và giám sát việc sử dụng thiết bị bảo hộ cá nhân của người lao động.

Tư khoá: tiếng ôn, nhà máy chế biến thực phẩm, thực hành phòng bệnh, điếc nghề nghiệp

\section{SUMMARY NOICE INDUCED AT WORK AND PREVENTION PRACTICE AMONG WORKERS AT A FOOD PROCESSING COMPANY IN PHU YEN}

Hearing loss is one of the most common occupational health issues in the world and in Vietnam. Sectors that have working environment polluted with were mining, gridding and food processing. This study aimed to investigate the situation at a food processing company and prevention practice among workers. The cross sectional study was conducted in 125 workers of the company 64 environment samples were collected among them 40 were for general noise and 24 for different octave ranges. Results show that $53.9 \%$ of environmental samples exceeded the national limit, it range from $74-93 \mathrm{dBA}$; section with highest noise level was separating section with noise level $91 \pm$ 1,83 dBA.Only $52.8 \%$ practice adequately on hearing loss prevention. Only $44 \%$ of woekers used PPE frequently, and only $31,5 \%$ used headset to protect their ears. It was recommended that the company should apply measures to reduce noise level at workd and supervise workers on using PPE while working. 